\title{
Late-season 'Valencia' Orange Mechanical Harvesting with an Abscission Agent and Low-frequency Harvesting
}

\author{
Jacqueline K. Burns ${ }^{1}$ \\ University of Florida, Institute of Food and Agricultural Sciences, Citrus \\ Research and Education Center, 700 Experiment Station Road, Lake Alfred, \\ FL 33850
}

Fritz M. Roka

Southwest Florida Research and Education Center, 2686 State Road 29 North, Immokalee, FL 34142

Kuo-Tan Li, Luis Pozo, and Richard S. Buker ${ }^{2}$

University of Florida, Institute of Food and Agricultural Sciences, Citrus Research and Education Center, 700 Experiment Station Road, Lake Alfred, FL 33850

Additional index words. 5-chloro-3-methyl-4-nitro-1H-pyrazole, fruit removal, trunk shaker, yield

Abstract. An abscission agent (5-chloro-3-methyl-4-nitro-1 $H$-pyrazole [CMNP]) at 300 $\mathrm{mg} \cdot \mathrm{L}^{-1}$ in a volume of $2810 \mathrm{~L} \cdot \mathrm{ha}^{-1}$ was applied to Valencia orange trees [Citrus sinensis (L.) Osb.] on 22 May 2004. At this time, immature and mature fruit were present on the tree simultaneously. Three days after application, fruit were mechanically harvested using a trunk-shake-and-catch system. The power to the shaker head was operated at full- or half-throttle (FT or HT, respectively), and the duration of trunk shaking was 2 seconds at FT or 4 seconds at FT and HT. Mature fruit removal percentage and number of immature fruit removed, and fruitlet weight and diameter were determined. Mature fruit removal percentage with 2 seconds at FT or 4 seconds at FT harvesting \pm CMNP, or 4 seconds at HT + CMNP was not significantly different and ranged between $89 \%$ to $97 \%$. Harvesting at 4 seconds HT without $C M N P$ removed significantly less mature fruit than any treatment. CMNP did not affect immature fruit removal by the trunk shaker. Harvesting at 4 seconds at HT removed significantly less immature fruit than 2 seconds at FT or 4 seconds at FT. No significant difference in fruitlet weight or diameter was measured between any trunk shaker harvest operation and CMNP treatment. Trunk shaking frequency was estimated to be 4.8 and 8.0 Hz at HT and FT, respectively. Yield in 2005 was determined on the same trees used for harvest treatments in 2004. CMNP did not impact yield. No significant difference in yield was seen between the hand-picked control and 4 seconds at HT, whereas yield in the remaining treatments was lower. The results demonstrate that $C M N P$ application combined with low frequency trunk shaker harvesting can achieve high percentage of mature fruit removal with no significant impact on return yield of the following crop.

In Florida, trunk and continuous canopy shake-and-catch systems harvest commercial orange groves at high fruit removal percentages and up to $20 \%$ cost savings (Brown, 2005). However, only $4.4 \%$ of the total orange bearing acreage, or 25,000 acres of processed oranges, were mechanically harvested in the 2004-05 season (Florida Agricultural Statistics Service 2004; reported to the Florida Citrus Commis-

Received for publication 26 Oct. 2005. Accepted for publication 28 Nov. 2006. The authors wish to thank Ana Redondo, Barbara Hyman, Marcus Timpner, Katrina Van Tonder, Rose Edwards and Coe-Collier Citrus Harvesting LLP for their expert assistance and cooperation. Use of trade names does not imply endorsement of the products named or criticism of similar ones not named.

${ }^{1}$ To whom reprint requests should be addressed; e-mail jkbu@uff.edu.

${ }^{2}$ Current address: Helena Chemical Company, 2405

N. 71 st Street, Tampa, FL 33619. sion, June 2005). A significant impediment to the adoption of mechanical harvesting has been the inability to harvest the entire crop mechanically. Processing oranges are harvested from November to mid-June, but the presence of young growing fruit along with mature fruit on the same tree after bloom raises concerns about mechanical harvesting, especially after 1 May. At this time, immature fruit are of sufficient size to be removed with mature fruit by the force of mechanical shaking, thus reducingnext season's yield. More than $33 \%$ of the total 'Valencia' acreage remains to be harvested after 1 May (Triangle Newsletter, 2005). Previous studies have documented subsequent year yield losses when trees were mechanically harvested midMay and later (Hedden et al., 1984; Roka et al., 2005; Whitney et al., 1975). Florida processing plants dictate grower harvest schedules. The growth in demand for NFC (not-from-concentrate) juice has increased pressure to hold fruit on the trees longer, sometimes stretching the harvest season into late June.

Adoption of mechanical harvest systems will likely not increase until it is feasible to harvest mature fruit after 1 May with little or no impact on the following year's yield. Hand harvest crews typically remain in Florida for the late season 'Valencia' harvest when work is ensured throughout the majority of the season. Labor is less likely to harvest oranges after 1 May when year-round work is not guaranteed and other crops can be harvested in cooler, more temperate climates.

We recently reported that use of the abscission agent 5-chloro-3-methyl-4-nitro$1 H$-pyrazole (CMNP) significantly loosened mature fruit and increased trunk and continuous canopy shaker harvesting capacity of 'Hamlin' and 'Valencia' (Burns et al., 2005). CMNP is a selective nonphytotoxic abscission agent over a wide concentration range (Burns, 2002). The objective of this work was to determine ifCMNP could be used with mechanical harvesting to facilitate harvesting after 1 May. In this report, CMNP application was combined with trunk shake-and-catch mechanical harvesting for late season 'Valencia' to show that high fruit removal percentages can be achieved and high yields maintained in the following crop when low frequency harvesting is used.

\section{Materials and Methods}

Plant material. A 4-ha (10-acre) block of 22-year-old 'Valencia' orange trees [Citrus sinensis (L.) Osb.] on Carrizo citrange [C. sinensis $\times$ Poncirus trifoliate (L.) Ref.] rootstock was selected in the Silver Strand North Groves near Immokalee, Fla. Within this block, 140 uniform trees spaced at $3.6 \mathrm{~m}$ in the row and $7.3 \mathrm{~m}$ between the rows were selected for study. Statistical analysis indicated no difference in clear trunk height (distance from the soil-trunk interface to the first scaffold), trunk circumference, and tree height or canopy diameter among plots (data not shown). Trees had an average clear trunk height and circumference of $1 \mathrm{~m}$ and $60 \mathrm{~cm}$, respectively, and were hedged and topped to achieve an average tree height and canopy diameter of 4.1 and $2.4 \mathrm{~m}$, respectively. Trees were divided into plots of five adjacent trees in the row separated by at least two guard trees. Treatments were replicated four times and arranged in a randomized complete block design. Ground fruit under test trees were removed before CMNP application.

CMNP application, harvesting and data collection. A trunk shaker equipped with a catch-frame (Coe-Collier Citrus Harvesting LLP, Immokalee, Fla.) was used for harvest. The shaker head was clamped to the trunk approximately $25 \mathrm{~cm}$ above the soil line. Trunk shake durations of 2 or $4 \mathrm{~s}$ per tree were used and chosen based upon commercial practice and previous work (Burns et al., 2005). Some attributes of the Coe-Collier trunk shaker, such as shaker head mass, are proprietary and not reported here. Shake times were monitored with a stop watch. Timing began when the canopy visibly began to shake and ended at the designated time by terminating power to the shaker head. 
The harvester operator maintained the power to the shaker head at full-throttle (FT) at the $2 \mathrm{~s}$ shake duration or eitherFT or half-throttle (HT) at the $4 \mathrm{~s}$ shake duration. On 22 May 2004, 0 or $300 \mathrm{mg} \cdot \mathrm{L}^{-1}(300 \mathrm{ppm}) \mathrm{CMNP}(17.2 \%$ a.i., as previously formulated by Abbott Laboratories, Chicago, Ill. [see Burns etal., 2003]) was applied in a $2810 \mathrm{~L} \cdot \mathrm{ha}^{-1}\left(300 \mathrm{gal} \cdot \mathrm{acre}^{-1}\right)$ volume with an air-blast sprayer (model MB-400-36 Pul-Blast; Rears Manufacturing Co., Eugene, Ore.). Spray solutions contained $0.125 \%$ (vol/vol) Kinetic adjuvant (Helena Chemical Co., Memphis, Tenn.). A hand-picked control was included; thus, a total of seven treatments were in the trial.Average hourly temperatures were obtained from the Florida Automated Weather Network's Immokalee weather station located about $2 \mathrm{~km}$ southwest of the test site at the SouthwestFlorida Research and Education Center (University of Florida, 2005). Temperature at the time of application (1000 HR) was $27.8^{\circ} \mathrm{C}$ and fell to a low of $15^{\circ} \mathrm{C}$ the following night. After CMNP application and until harvest $3 \mathrm{~d}$ afterward, the lowest and highest hourly temperatures were 15 and $32.8^{\circ} \mathrm{C}$, respectively, and averaged $23.9^{\circ} \mathrm{C}$ during this time.

On the day of spray application (22 May 2004) and before harvesting commenced ( 25 May 2004), fruit detachment force (FDF) was measured from ten randomly selected fruit in each treatment plot. FDF was measured as previously described (Pozo et al., 2004). Trees in the hand-picked controls were harvested and the fruit weighed to calculate yield. Fruit were harvested by the trunk shaker in the remaining treatments and removed from the grove. Fruit remaining in the tree after harvesting (gleaned fruit) were removed by hand and weighed. Mature fruit removal percentage was calculated by dividing the weight of the gleaned fruit by the average total fruit weight harvested from the hand-picked controls and multiplying by 100 . Immature fruit removed by the trunk shaker were collected in each plot and transported to the laboratory to count, weigh and measure fruitlet diameter. A year later (6 May 2005), test trees were hand-harvested and the fruit weighed in each treatment plot to determine the effect of trunk shaking and CMNP application in 2004 on yield in 2005 .

Trunk shaker frequency. Frequency of the trunk shaker operated at FT and HT in May 2004 was estimated in a separate experiment conducted in an adjacent block on 10 Mar 2005 with a trunk shaker identical to the unit used in the 2004 trial. A tachometer was connected to the harvester engine output (rpm) so that power to the shaker head could be monitored. An accelerometer (PCB 35B33, PCB Piezotronics, Inc., Depew, N.Y.) connected to a WavePort version PE8 high-speed portable data acquisition systemutilizing WaveView version 7.14.15 software (IOtech, Inc., Cleveland, Ohio) was used. The accelerometer was attached to the main trunk with duct tape about $30 \mathrm{~cm}$ above the top of the shaker clamp. Raw data were collected and displayed as a function of elapsed time, and frequency was calculated. Frequency measurements $[\mathrm{Hz},(\mathrm{cycles} / \mathrm{sec})]$ were taken at FT (>4000 rpm), HT (2000 rpm) and quarterthrottle $(1000 \mathrm{rpm})$. The frequency at each rpm level was tested twice on three trees with similar trunk circumference and canopy height as 2004 test trees.

Data analysis. Removal, yield, and fruitlet number, diameter and weight data were analyzed as a two-way factorial with harvest operation and CMNP as main factors. Analysis of variance was performed using the General Linear Model function within the SAS statistical package(SAS Institute, Cary, N.C.). Arc sin transformation was performed on percentage data to normalize distribution of variance. Frequency data were subjected to a one-way analysis of variance. One-wayANOVA was run on all data and means separated by Duncan's multiple range test.

\section{Results}

$F D F$, mature, and immature fruit removal in 2004. FDF averaged $11.2 \mathrm{~kg}$ before spray application. Immediately before harvest, FDF averaged $11.3 \mathrm{~kg}$ in control plots and $4.8 \mathrm{~kg}$ in plots sprayed with CMNP. Postapplication fruit drop was not directly measured but visually estimated to be $<2 \%$ of the total yield, with no visual differences between sprayed and unsprayed plots. The harvest operation and CMNP significantly influenced mature fruit removal (Fig. 1). AtFT, mature fruit removal percentage was $89 \%$ to $92 \%$ with either shake duration. At HT, fruit removal was much lower. Application of CMNP numerically increased mature fruit removal percentage at either shake time or throttle position. Differences were greater and statistically significant in the $4 \mathrm{~s}$ HT harvest treatment. CMNP had no significant effect on the number of immature fruit removed per tree, or average diameter or weight of immature fruit removed (Table 1). The harvesting operation significantly impacted immature fruit removal. More immature fruit were removed with the 4 s FT harvest treatment. Reducing shake time to $2 \mathrm{~s}$ at the same throttle position or reducing the throttle to HT significantly decreased immature fruit removal.

Frequencyat trunkshaker throttle positions.

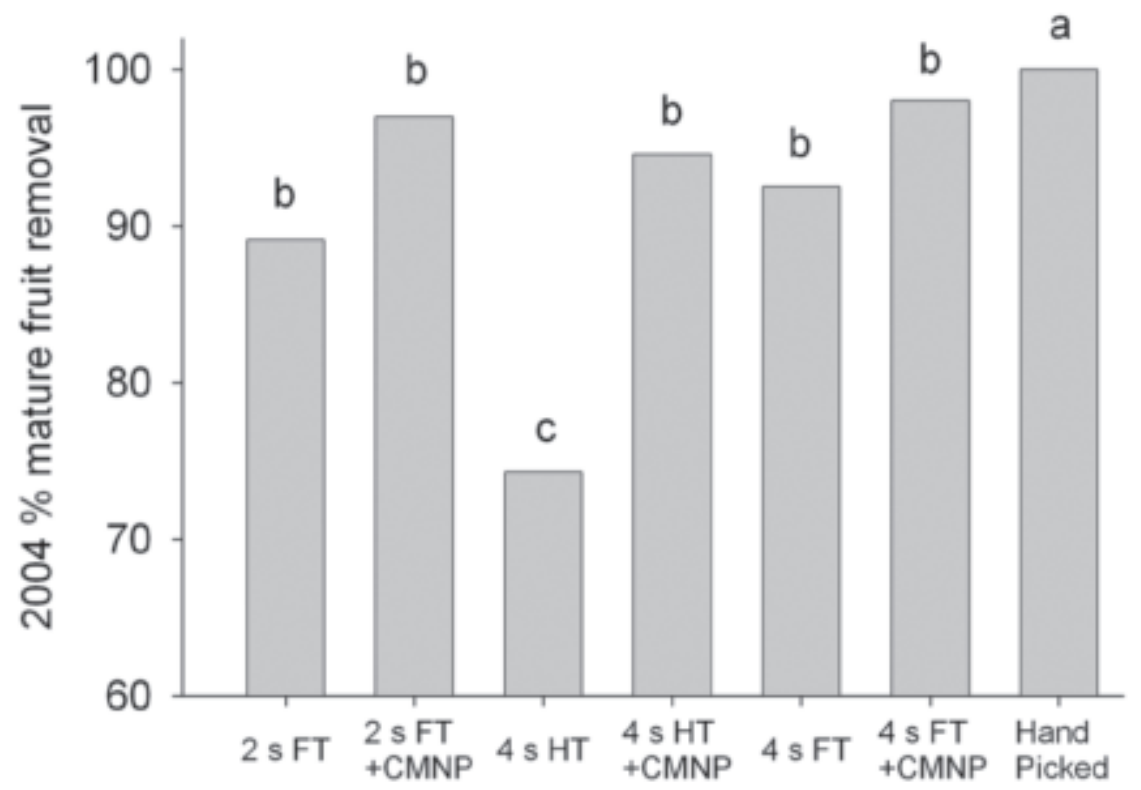

Fig. 1. Mature fruit removal percentage in 2004 after harvest with a trunk shaker or by hand. 'Valencia' trees were sprayed with $300 \mathrm{mg} \cdot \mathrm{L}^{-1} \mathrm{CMNP}$ on 22 May 2004 and harvested on 25 May 2004. FT = fullthrottle; HT = half-throttle. Means followed by the same letter are not different as judged by Duncan's multiple range test $(P \leq 0.01)$.

Table 1. Number, weight $(\mathrm{g})$ and diameter $(\mathrm{cm})$ of immature fruit removed as affected by the harvest operation and CMNP. 'Valencia' trees were sprayed with CMNP on 22 May 2004 and harvested on 25 May 2004 with 2 or 4 s trunk shake duration at full- or half-throttle power to the shaker head.

\begin{tabular}{|c|c|c|c|c|}
\hline $\begin{array}{l}\text { Harvest } \\
\text { operation }^{z}\end{array}$ & $\begin{array}{c}\text { CMNP } \\
\left(\mathrm{mg} \cdot \mathrm{L}^{-1}\right)\end{array}$ & $\begin{array}{c}\text { Fruitlets/tree } \\
\text { (no.) }\end{array}$ & $\begin{array}{l}\text { Wt } \\
(\mathrm{g})\end{array}$ & $\begin{array}{l}\text { Diam } \\
(\mathrm{cm})\end{array}$ \\
\hline $2 \mathrm{~s}$ at FT & 0 & $212.7 b^{y}$ & 14.9 & 3.1 \\
\hline $2 \mathrm{~s}$ at FT & 300 & $185.3 \mathrm{~b}$ & 16.2 & 3.1 \\
\hline $4 \mathrm{~s}$ at $\mathrm{HT}$ & 0 & $149.0 \mathrm{~b}$ & 15.0 & 3.0 \\
\hline $4 \mathrm{~s}$ at $\mathrm{HT}$ & 300 & $114.4 \mathrm{~b}$ & 15.6 & 2.9 \\
\hline $4 \mathrm{~s}$ at FT & 0 & $306.7 \mathrm{a}$ & 15.7 & 3.1 \\
\hline $4 \mathrm{~s}$ at FT & 300 & $370.1 \mathrm{a}$ & 13.7 & 3.0 \\
\hline \multicolumn{5}{|l|}{$P$} \\
\hline Harvest operation & & $<0.001$ & 0.575 & 0.067 \\
\hline CMNP & & 0.983 & 0.994 & 0.658 \\
\hline $\mathrm{H} \times \mathrm{C}$ & & 0.152 & 0.125 & 0.590 \\
\hline
\end{tabular}

${ }^{\mathrm{z}} \mathrm{FT}=$ full-throttle $(8.0 \mathrm{~Hz}) ; \mathrm{HT}=$ half-throttle $(4.8 \mathrm{~Hz})$.

y Means followed by the same letter in a column are not significantly different as judged by Duncan's multiple range test, $P \leq 0.01$. 


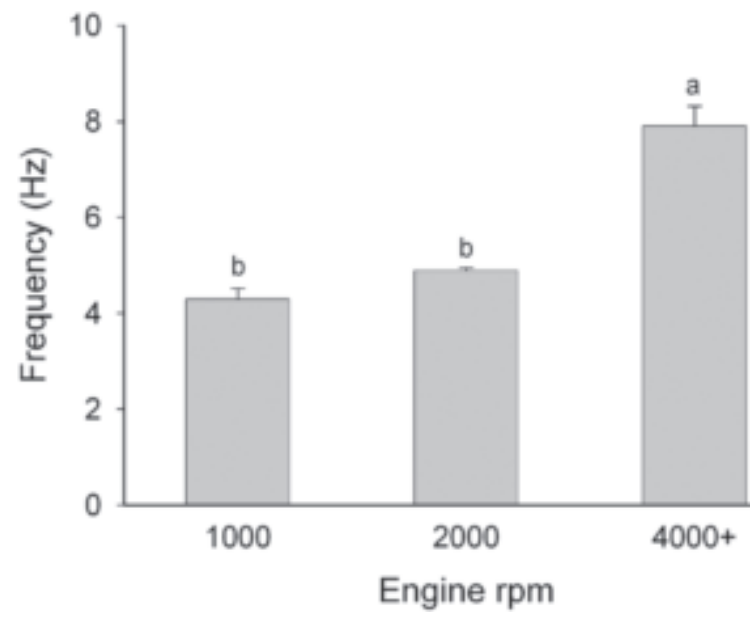

Fig. 2. Frequency of the trunk shaker at various engine rpm settings. Measurements were made on 10 Mar. 2005 in an adjacent block of 'Valencia' trees used in the 25 May 2004 trial. Vertical bars represent standard error. Means followed by the same letter are not different as judged by Duncan's multiple range test $(P \leq 0.001)$.

Table 2. Yield in 2005 as affected by 2004 harvest operation and CMNP. 'Valencia' trees were harvested with the trunk shaker with 2 or $4 \mathrm{~s}$ shake duration at full- or half-throttle power to the shaker head or hand-picked on 25 May 2004. Yield was determined on 6 May 2005.

\begin{tabular}{lcc}
\hline $\begin{array}{l}\text { Harvest } \\
\text { operation }\end{array}$ & $\begin{array}{c}\mathrm{CMNP} \\
\left(\mathrm{mg} \cdot \mathrm{L}^{-1}\right)\end{array}$ & $\begin{array}{c}\text { Yield in 2005 } \\
(\mathrm{kg} / \text { tree })\end{array}$ \\
\hline Hand-picked & 0 & $123.6 \mathrm{a}^{2}$ \\
$2 \mathrm{~s}$ at FT & 0 & $78.4 \mathrm{c}$ \\
$2 \mathrm{~s}$ at FT & 300 & $90.4 \mathrm{bc}$ \\
$4 \mathrm{~s}$ at HT & 0 & $114.6 \mathrm{ab}$ \\
$4 \mathrm{~s}$ at HT & 300 & $102.1 \mathrm{ab}$ \\
$4 \mathrm{~s}$ at FT & 0 & $72.6 \mathrm{c}$ \\
$4 \mathrm{~s}$ at FT & 300 & $68.0 \mathrm{c}$ \\
$P$ & & \\
Harvest operation & & 0.001 \\
CMNP & & 0.801 \\
H $\times$ C & & 0.330 \\
\hline
\end{tabular}

${ }^{2}$ Means followed by the same letter in a column are not significantly different as judged by Duncan's multiple range test, $P \leq 0.01$.

${ }^{y} \mathrm{FT}=$ full-throttle $(8.0 \mathrm{~Hz}) ; \mathrm{HT}=$ half-throttle $(4.8 \mathrm{~Hz})$.

Increasing engine rpm increased frequency of trunk shaking (Fig. 2). At FT, engine rpm exceeded the maximum tachometer read-out of 4000; nevertheless, frequency was determined to be $8.0 \mathrm{~Hz}$ and significantly greater than other engine rpm settings tested. Frequencies determined at 2000 (HT) and 1000 (quarterthrottle) engine rpm settings were 4.8 and 4.2 $\mathrm{Hz}$, respectively, and not significantly different from one another.

Yield in 2005. Application of CMNP in 2004 did not significantly alter yield in 2005 (Table 2). In contrast, the 2004 harvest operation significantly affected 2005 yield. The FT harvesting operation at 4 or $2 \mathrm{~s}$ in 2004 reduced yield in 2005 .

\section{Discussion}

A significant impediment to adoption of mechanical harvesting in Florida has been the inability to harvest the entire crop throughout the season. Several studies have documented significant yield losses when mechanical harvesting occurs after 1 May (Hedden et al., 1984; Roka et al., 2005; Whitney et al., 1975). As a result, the citrus industry is currently committed to hand crews to harvest the final $33 \%$ of the late-season 'Valencia' oranges. Solving the late-season problem will have several positive and multiplicative impacts on the economic feasibility of mechanical harvesting systems. First, the economic benefits of mechanical harvesting that have been documented for acreage harvested before 1 May (Brown, 2005) can be extended through the entire season. Second, alleviating the requirement of hand-harvesting after 1 May releases the need to employ some hand crews through the early and mid season harvest, thereby increasing the number of early and mid season acres for mechanical harvesting systems. Finally, as the mechanical harvesting season is extended beyond 1 May and the total number of acres mechanically harvested increases, capacity of existing machines will be more fully used. As machine capacity increases, harvesting costs go down. Lower harvest costs will accelerate the adoption of mechanical harvesting systems.

Reduction in yield when 'Valencia' oranges are mechanically harvested after 1 May (Hedden et al., 1984; Roka et al., 2005; Whitney et al., 1975) is not due to negative impacts on tree health, but rather removal of immature fruit by the mechanical harvester. In general, the number of immature fruit removed with a trunk shaker increased with increasing fruitlet diameter (Whitney, 1975). Immature fruit loss and subsequent yield reductions were documented when fruitlet diameter was 1.25 $\mathrm{cm}$ or greater (Hedden et al., 1984; Whitney et al., 1988). At that time it was postulated that immature fruit loss and yield reduction could be minimized by decreasing the force of shaking and utilizing a selective abscission compound. In the study reported here, young fruit diameter was approximately $3.0 \mathrm{~cm}$ at the time of harvest, which made them vulnerable to removal by mechanical harvesting. The fact that immature fruit weight and diameter were similar across all treatments indicates that differences in removal were not related to fruitlet size differences but rather the force of the harvest treatment.

The force applied to a tree with a trunk shaker can be manipulated by altering the energy transmitted to the shaker head; in doing so, attributes such as shaking frequency can be changed and fruit removal can be affected (Fridley 1983; Whitney et al. 1988). Other attributes such as trunk displacement and amplitude can be affected, but were not measured in our study. Hedden et al. (1988) reported that as trunk shaking energy increased, immature fruit removal increased. In the current study, more immature fruit were removed at $4 \mathrm{~s}$ FT $(4000+$ engine rpm, about $8.0 \mathrm{~Hz})$ than $4 \mathrm{~s} \mathrm{HT}$
(2000 engine rpm, about $4.8 \mathrm{~Hz}$ ) harvesting, and simply reducing the duration of shake at FT was not sufficient to reduce fruitlet loss to the level of the HT treatment. As expected, operating the trunk shaker at FT improved percentage mature fruit removal compared to HT harvesting, but the following year's crop was greatly reduced. Application of CMNP loosened mature fruit and made them easier to remove; thus, trees treated with CMNP and harvested at HT detached readily at the fruit abscission zone and had fruit removal percentages comparable to FT harvesting, with no significant impact on the following year's yield. The advantage of a selective abscission agent such as CMNP is realized over a 2-year span: high fruit removal percentages with HT or low frequency harvesting in year one followed by yields comparable to hand harvested trees in year two.

In conclusion, this study shows that HT or low frequency mechanical harvesting with a trunk shaker combined with CMNP application will enable late season 'Valencia' harvesting because high fruit removal percentages can be achieved with no significant yield reduction in the following year's crop. Additional work and measurements will be needed to fully understand the interaction of the trunk shaker with the tree and to associate specific attributes of this relationship with success in late season harvest of 'Valencia'. Multiple years of research with citrus has demonstrated no effect of trunk shaking at recommended durations or CMNP application at recommended rates on tree health and yield (Hedden et al., 1988; Li and Syvertsen, 2005; Whitney et al., 2000). Additional work will focus on use of CMNP with canopy-shake-and-catch systems during late season 'Valencia' harvest to determine if the same benefits can be shown with lowfrequency harvesting. Integration of CMNP into a mechanical harvesting system used throughout the entire season will depend on successful registration of the compound and final cost to the grower.

\section{Literature Cited}

Brown, G.K. 2005. New mechanical harvesters for the Florida citrus juice industry. HortTechnology 15:69-72.

Burns, J.K. 2002. Using molecular biology tools to identify abscission materials for citrus. HortScience 37:459-464.

Burns, J.K., R.S. Buker, and F.M. Roka. 2005 Mechanical harvesting capacity in sweet orange is increased with an abscission agent. HortTechnology 15:758-765.

Burns, J.K., L.V. Pozo, R.Yuan, and B. Hockema. 2003. Guanfacine and clonidine reduce defoliation and phytotoxicity associated with abscission agents. J. Amer. Soc. Hort. Sci. 128:42-47.

Florida Agricultural Statistics Service. 2004. Citrus Summary 2003-04. Fla. Dep. Agric. Consum. Serv. 8 Aug. 2005. http://www.nass.usda.gov/ fl/rtoc0ci.htm

Fridley, R.B. 1983. Vibration and vibratory mechanisms for the harvest of tree fruits, p.157-188 In: M. O'Brien, B.F. Cargill, and R.B. Fridley (eds.). Principles and practices for harvesting and handling fruits and nuts. AVI, Westport, Conn.

Hedden, S.L., D.B. Churchill, and J.D. Whitney. 1984. Orange removal with trunk shakers. Proc. 
Fla. State Hort. Soc. 97:47-50.

Hedden, S.L., D.B. Churchill, and J.D. Whitney. 1988. Trunk shakers for citrus harvesting. Part II: Tree growth, fruit yield and removal. Appl. Eng. Agr. 4:102-106.

Li, K.-T. and J.P. Syvertsen. 2005. Mechanical harvesting has little effect on water status and leaf gas exchange in citrus trees. J. Amer. Soc. Hort. Sci. 130:661-666.

Pozo, L., R. Yuan, I. Kostenyuk, F. Alferez, G.Y. Zhong, and J.K. Burns. 2004. Differential effects of 1-methylcyclopropene on citrus leaf and mature fruit abscission. J. Amer. Soc. Hort.
Sci. 129:473-478.

Roka, F.M., J.K. Burns, and R.S. Buker. 2005. Mechanical harvesting without abscission agentsYield impacts on late season 'Valencia' oranges. Proc. Fla. State Hort. Soc. 118:25-27.

Triangle. 13 May 2005. Nwsltt. Fla. Citrus Mutual $55(28)$.

University of Florida. 2005. Florida automated weather network. Univ. Fla., Inst. Food Agr. Sci. 8 Aug. 2005. http://fawn.ifas.ufl.edu/data

Whitney, J.D. 1975. Orange yield and removal studies with air and trunk shakers using two abscission chemicals. Proc. Fla. State Hort.
Soc. 88:120-124.

Whitney, J.D., D.B. Churchill, S.L. Hedden, and G.H. Smerage. 1988. Trunk shakers for citrus harvesting. Part I: Measured trunk shaker and tree trunk motion. Appl. Eng. Agr. 4:93-101.

Whitney, J.D., U. Hartmond, W.J. Kender, M. Salyani, and J.K. Burns. 2000. Abscission chemicals affect trunk shaker orange removal. Proc. Fla. State Hort. Soc. 113:93-96.

Whitney, J.D., H.R. Sumner, and S.L. Hedden. 1975. Foliage shaker for citrus harvesting. Part II: Harvesting trials. Trans. Amer. Soc. Agr. Eng. 18:70-73. 